\title{
Yield and phenological indices of wheat as affected by exogenous fertilization of Zinc and Iron
}

\author{
Arshad Jalal' ${ }^{1}$, Shahen Shah ${ }^{2} \oplus$, Marcelo Carvalho Minhoto Teixeira Filho ${ }^{1} \oplus$, Ayesha Khan ${ }^{2} \odot$, \\ Tariq Shah²®, Zawar Hussain²®, Muhammad Younis²®, Muhammad llyas²®

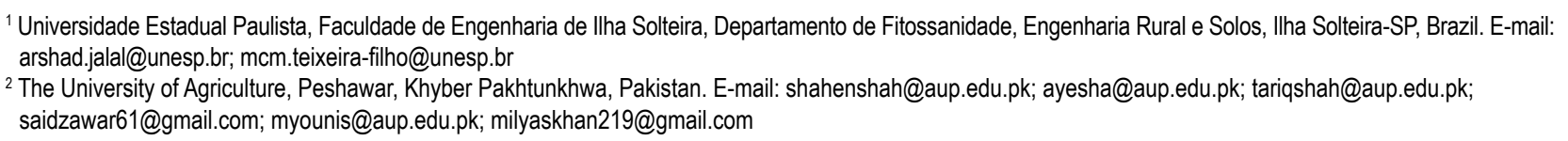

ABSTRACT: Micronutrients (zinc and iron) play a vital role in the functioning of all living organisms. These nutrients are indispensable for plant nourishment and development - though required in small amount. The current research work was performed at the Agronomy Research Farm, The University of Agriculture Peshawar in winter, 2015-16. Combinations of soil applied $\mathrm{Zn}$ levels $\left(5,10,15\right.$ and $\left.20 \mathrm{~kg} \mathrm{ha}^{-1}\right)$ and Fe levels $\left(5,10,15\right.$ and $\left.20 \mathrm{~kg} \mathrm{ha}^{-1}\right)$ with a control were allotted randomly to the experimental units using randomized complete block design. The results elucidated that days to anthesis, plant height, productive tillers, yield and yield components of wheat were significantly inclined with $\mathrm{Zn}$ and Fe levels. The plots enriched with $15 \mathrm{~kg} \mathrm{Zn} \mathrm{ha-1}^{-1}$ and $10 \mathrm{~kg} \mathrm{Fe} \mathrm{ha}^{-1}$ exhibited higher grain yields (3775 and $3802 \mathrm{~kg} \mathrm{ha}^{-1}$, respectively). Results conceded that the interaction for Zn and Fe was significant for days to anthesis. It was concluded that the plots fertilized with $15 \mathrm{~kg} \mathrm{Zn} \mathrm{ha}^{-1}$ and $10 \mathrm{~kg} \mathrm{Fe} \mathrm{ha}^{-1}$ resulted in improved yield and yield components. Hence, fertilization of plots with $15 \mathrm{~kg} \mathrm{Zn} \mathrm{ha}^{-1}$ and $10 \mathrm{~kg} \mathrm{Fe} \mathrm{ha}^{-1}$ is recommended for improved wheat yield in the agro-climatic condition of Peshawar.

Key words: grain yield; growth; micronutrients; Triticum aestivum

\section{Rendimento e índices fenológicos de trigo afetados por fertilização exógena de zinco e ferro}

RESUMO: Os micronutrientes (zinco e ferro) desempenham um papel vital no funcionamento de todos os organismos vivos. Estes nutrientes são indispensáveis para a nutrição e desenvolvimento das plantas - embora necessários em pequena quantidade. $O$ atual trabalho da pesquisa foi realizado na Agronomy Research Farm, Universidade da Agricultura Peshawar no inverno, 2015-2016. Combinações de níveis de Zn aplicados no solo (5, 10, 15 e $\left.20 \mathrm{~kg} \mathrm{ha}^{-1}\right)$ e Fe (5, 10, 15 e $\left.20 \mathrm{~kg} \mathrm{ha}^{-1}\right) \mathrm{com}$ um controle foram distribuídas aleatoriamente para as unidades experimentais usando o delineamento experimental em blocos ao acaso. Os resultados mostraram que dias para antese, altura de planta, perfilhos produtivos, componentes de produção e rendimento biológico de trigo foram significativamente influenciados pelas doses de $\mathrm{Zn}$ e Fe. As parcelas enriquecidas com 15 $\mathrm{kg} \mathrm{Zn} \mathrm{ha-1} \mathrm{e} 10 \mathrm{~kg} \mathrm{Fe} \mathrm{ha-1}$ apresentaram maiores rendimentos de grãos (3775 e $3802 \mathrm{~kg} \mathrm{ha}^{-1}$, respectivamente). Os resultados mostraram que a interação para $\mathrm{Zn}$ e Fe foi significativa para dias a antese. Concluiu-se que as parcelas adubadas com 15 $\mathrm{kg}$ de $\mathrm{Zn} \mathrm{ha-1}$ e $10 \mathrm{~kg}$ de Fe ha-1 resultaram uma produção melhor dos componentes. Assim, a adubação de parcelas com 15 $\mathrm{kg}$ de $\mathrm{Zn} \mathrm{ha}{ }^{-1}$ e $10 \mathrm{~kg}$ de Fe ha-1 é recomendada para melhorar o rendimento de trigo na condição agroclimática de Peshawar.

Palavras-chave: produtividade de grãos; crescimento; micronutrientes; Triticum aestivum 


\section{Introduction}

Micronutrients deficiencies are getting attention global wise. The micronutrients deficiency occurs in the result of high yielding cultivars and excessive utilization of macro nutrients like nitrogen $(\mathrm{N})$, phosphorus $(\mathrm{P})$, and potassium (K). Almost $50 \%$ of the agricultural lands around the world are $\mathrm{Zn}$ deficient for the cereal productivity (Cakmak 2008). Our planet soil is naturally comprised of 1 to $5 \%$ of the $\mathrm{Fe}$ however it has an imperative role in the soil properties (phosphorus accumulation, ions inequality, soils texture and compaction of soil) (Mengel \& Kirkby, 2001). Moreover, the excessive bicarbonate and high $\mathrm{pH}$ of Pakistani soil inhibit the availability of $\mathrm{Zn}$ and Fe to the plants (Jalilvand et al., 2014). Micronutrients are needed in trace quantity for the crop growth and development but still there importance cannot be negotiated and therefore deficiency of micronutrients may be in soil, food or feed has become the cry of the day (Tahir et al., 2013).

The most reliable source of $\mathrm{Zn}$ is zinc sulphate which is prominently involved in various enzymatic activities, nitrogen metabolism and protein formation (Cakmak, 2002). $\mathrm{Zn}$ is an active and essential nutritional microelement for a number of biochemical activities and hence efficiently associated with quantitative and qualitative yield of crops (Mousavi et al.,2013). It has key role in cellular and physiological processes of all living organisms and enhancing protein contents in seed whereas its deficiency in human leads to memory loss, skin issues and muscles weakness (Hafeez et al., 2013).

Iron (Fe) has imperative role in chlorophyll synthesis, respiration and photosynthesis which result in crop growth and development. It has vital role in the breakdown of nucleic acid and carbohydrates into nitrate and ammonium in plant cell (Havlin et al., 2014). The ultimate reason of Fe deficiency in the edible portion of the crop and human is due to the Fe deficient (White \& Broadley, 2009).

As $\mathrm{Zn}$ and Fe are the important micronutrients both for plant and human. The current study was therefore conducted to evaluate the main effect of $Z n$ and Fe as well as to identify their interaction on phenology, yield components and yield of wheat crop in the agro climatic zone of Peshawar.

\section{Material and Methods}

\section{Experimental details and location}

An experiment entitled "Phenology and yield of wheat as affected by exogenous fertilization of zinc and iron" was designed at the Agronomy Research Farm (ARF) of The University of Agriculture (UoA), Peshawar in winter 2015-16. The experimental farm is situated at $34.01^{\circ} \mathrm{N}$ latitude, $71.35^{\circ} \mathrm{E}$ longitude and an altitude of $350 \mathrm{~m}$ above sea level. Peshawar is situated in the north of Indian Ocean at nearly $1600 \mathrm{~km}$ with continental climate. The research farm is irrigated (surface irrigation) by Warsak Canal from River Kabul. Rainfall, temperature and relative humidity data were collected and are summarized in Figure 1.

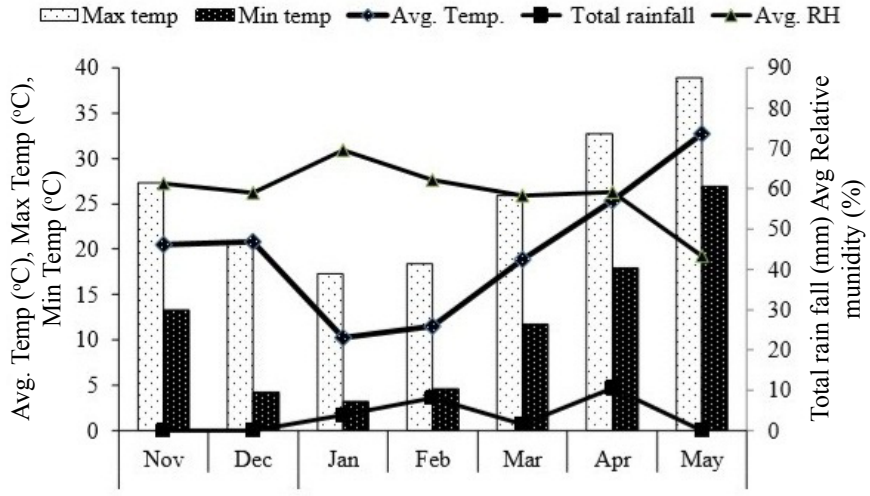

Source: Digital weather station of Agronomy Research Farm- The University of Agriculture Peshawar- Pakistan.

Figure 1. Meteorological data for wheat growing season from November, 2015 to May, 2016.

\section{Soil analysis}

The soil of the research site is clay loam, alkaline in reaction with electrical conductivity of $0.08 \mathrm{dSm}^{-1}$. The $\mathrm{N}, \mathrm{P}$ and $\mathrm{K}$ contents of the soil were $1 \%, 4.52 \mathrm{mg} \mathrm{kg}^{-1}$ and $70.2 \mathrm{mg} \mathrm{kg}^{-1}$ respectively. The soil was deficit in organic matter (Table 1). Soil $\mathrm{N}$ content was determined with the help of kjeldahl apparatus (Bremner \& Malvaney, 1982). Soil P, K, Zn and Fe content were determined by using AB-DTPA extracting solution as described by Soltanpour \& Schwab (1977) and was determined by spectrophotometer, flame photometer and atomic absorption spectroscopy, respectively. Organic matter of soil was determined by following the Walky-Black technique as demonstrated by Nelson \& Sommers (1996). Soil pH was determined by using $\mathrm{pH}$ meter (Mclean, 1982). Electrical conductivity of soil extract was determined by electrical conductivity meter (Black, 1965a, b).

Table 1. Chemical properties of pre harvest soil sample. The University of Agriculture Peshawar, 2016.

\begin{tabular}{ccc}
\hline Soil properties & Units & Values \\
\hline $\mathrm{N}$ content & $\%$ & 0.1 \\
$\mathrm{P}$ content & $\mathrm{mg} \mathrm{kg}^{-1}$ & 4.52 \\
$\mathrm{~K}$ content & $\mathrm{mg} \mathrm{kg}^{-1}$ & 70.2 \\
Zn content & $\mathrm{mg} \mathrm{kg}^{-1}$ & 1.18 \\
Fe content & $\mathrm{mg} \mathrm{kg}^{-1}$ & 0.65 \\
Organic matter & $\%$ & 1.53 \\
pH & ---- & 8.67 \\
Electrical conductivity & $\mathrm{dS} \mathrm{m}{ }^{-1}$ & 0.08 \\
\hline
\end{tabular}

Source: The author's own elaboration.

\section{Experimental layout}

The experiment was consisting of two factors (Zinc and Iron) each having four levels; 5, 10, 15 and $20 \mathrm{~kg} \mathrm{ha}^{-1}$, respectively. All the treatments combinations and a control $(16+1)$ were randomly allotted to the experimental units using randomized complete block design (RCBD) with 4 replications. $\mathrm{Zn}$ and $\mathrm{Fe}$, as per their levels were applied from $\mathrm{ZnSO}_{4} \cdot 7 \mathrm{H}_{2} \mathrm{O}$ \& $\mathrm{FeSO}_{4} \cdot 7 \mathrm{H}_{2} \mathrm{O}$ sources respectively.

\section{Crop husbandry}

Wheat variety 'Atta Habib-2010' was planted at the rate of $120 \mathrm{~kg} \mathrm{ha}^{-1}$ on flat beds with $30 \mathrm{~cm}$ apart rows. Plot size was 
$2.4 \times 4 \mathrm{~m}$. The recommended dose of nitrogen $\left(120 \mathrm{~kg} \mathrm{ha}^{-1}\right)$ was applied from urea in two equal splits with $\mathrm{Zn}$ and Fe. Phosphorus was applied in the form of DAP. Keeping in view the supply of sulfur while applying $\mathrm{Zn}$ as $\mathrm{ZnSO}_{4} .7 \mathrm{H}_{2} \mathrm{O} \& \mathrm{Fe}$ as $\mathrm{FeSO}_{4} 7 \mathrm{H}_{2} \mathrm{O}$ the supply of sulfur was made uniform in entire plots by utilizing ammonium sulfate $\left(\left(\mathrm{NH}_{4}\right)_{2} \mathrm{SO}_{4}\right)$ as nitrogencum-sulfur source, rest of nitrogen $(\mathrm{N})$ was maintained from the urea. Irrigation was adjusted on crop requirement basis whereas standard and constant agronomic practices were maintained for the entire treatments.

\section{Parameters evaluated in the experiment}

Data on days to anthesis were noted when $80 \%$ plants produce spike in each of the treatment. Days were totaled from the seeding date till the date of completion of $80 \%$ spikes in each plot. The productive tillers $\mathrm{m}^{-2}$ were documented by calculating the fertile tillers at three randomly chosen positions in a meter long row and then converted into $\mathrm{m}^{2}$ area via the formula:

Productive tillers $\left(\mathrm{m}^{-2}\right)=\frac{\text { Total productive tillers counted }}{\text { Row }- \text { row distance } \times \text { Row length } \times \text { No. of rows }}$

At physiological maturity, ten plants were selected at random for the plant height and then average was taken. Grains of ten randomly selected spikes were counted and then averaged. For data of 1000- grains weight; 1000 grains were counted and weighed with electronic balance. Grains of four central rows were weighed for grain yield and then converted into $\mathrm{kg} \mathrm{ha}^{-1}$, using formula:

Grain yield $\left(\mathrm{kg} \mathrm{ha}^{-1}\right)=\frac{\text { Grain yield in four central rows }}{\text { Row }- \text { row distance }(\mathrm{m}) \times \text { Row length }(\mathrm{m}) \times \text { No. of rows }} \times 10000$

\section{Results and Discussion}

Wheat is a determinate crop which is determined by vegetative and reproductive stages. As the vegetative growth duration ends, wheat crop is reaching to start flowering (anthesis). Days to anthesis was significantly affected by different zinc $(\mathrm{Zn})$ and iron $(\mathrm{Fe})$ levels. The treatments against control were found significant. The interaction of $\mathrm{Zn}$ with Fe was also significant (Table 2). Mean values of the data revealed that $\mathrm{Zn}$ at the rate of $20 \mathrm{~kg} \mathrm{ha}^{-1}$ took fewer days to anthesis (120). It was further shown that late anthesis (124) was recorded at $5 . \mathrm{kg} \mathrm{Zn} \mathrm{ha}^{-1}$. Among different Fe levels, more days to anthesis (124) were recorded for $F e$ at the rate of $20 \mathrm{~kg} \mathrm{ha}^{-1}$. Early anthesis (120) was observed at $5 \mathrm{~kg} \mathrm{Fe} \mathrm{ha}^{-}$ ${ }^{1}$. More days to anthesis (126) were observed at control as compare to the treated plots (122).The interactive effect of $\mathrm{Zn}$ and Fe exhibited that increasing $\mathrm{Zn}$ level decreased days to anthesis at all levels of Fe except $5 \mathrm{~kg} \mathrm{Fe} \mathrm{ha}^{-1}$ whereas no decrease in days to anthesis was observed with increasing $\mathrm{Zn}$ levels (Figure 2). Vigorous crop growth and precedence in the anthesis might be because of the reason that $Z n$ has a vital role in auxin formation, metabolism, cell expansion, biochemical

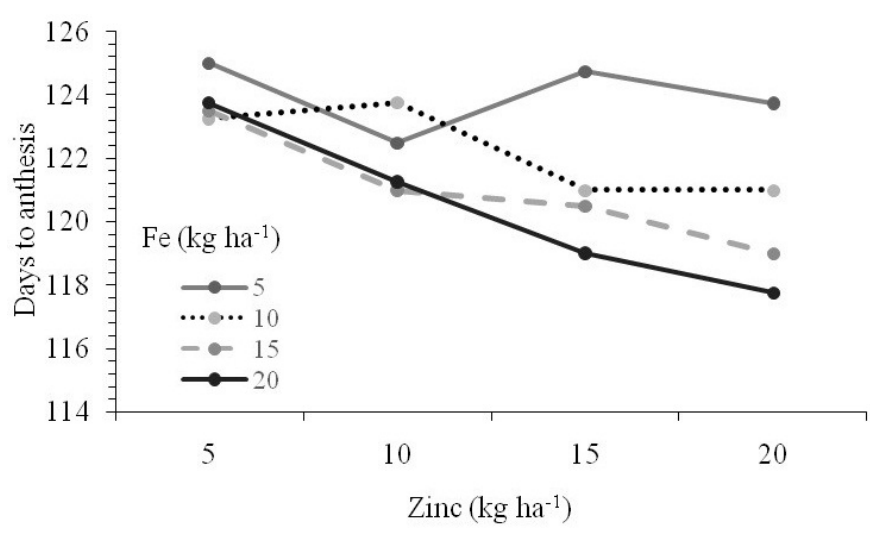

Source: MS Excel designed grap with original data from first author's master thesis.

Figure 2. Interaction of zinc and iron for days to anthesis of wheat. The University of Agriculture Peshawar, 2016.

activities and induction of primordia for reproductive components (Keram et al., 2014). Balanced fertilization of Fe and $\mathrm{Zn}$ promotes early tillering, early booting, early anthesis, spike length and grain spike ${ }^{-1}$ (Jalilvand et al., 2014). A detailed literature exposes that micro element as a mineral and chelating agent when provide sole or in combination improved growth and yield (Mosanna \& Behrozyar, 2015).

The number of productive tillers has vital importance in the determination and achieving of final yield in cereal. Analysis of variance revealed that productive tillers were suggestively influenced by $\mathrm{Zn}$ and Fe. The comparison of control with the treatment revealed significant differences, while the interactive effect of $\mathrm{Zn}$ and Fe was illustrated insignificant (Table 2). Means of the data presented that $\mathrm{Zn}$ at the rate of $15 \mathrm{~kg} \mathrm{ha}^{-1}$ resulted in higher productive tillers (299), which was statistically similar with the number of productive tillers (293) produced with the $10 \mathrm{~kg} \mathrm{Zn} \mathrm{ha}^{-1}$. The productive tillers (281) were lower with $5 \mathrm{~kg} \mathrm{Zn} \mathrm{ha}^{-1}$. Among different Fe levels, Fe at the rate of $10 \mathrm{~kg} \mathrm{ha}^{-1}$ produced higher productive tillers (298), which was statistically at par with the number of productive tillers (296) attained with the $5 \mathrm{~kg} \mathrm{Fe}$ $\mathrm{ha}^{-1}$. Lower number of productive tillers (282) was attained with the $20 \mathrm{~kg} \mathrm{Fe} \mathrm{ha-1.} \mathrm{The} \mathrm{control} \mathrm{plots} \mathrm{against} \mathrm{fertilized}$ plots produced lower number of productive tillers (244). This might be due to the fact that zinc application has key role in metabolic, physiological and biochemical processes which improve morphological characters of the plant and assimilates partitioning to the spikes (Vankhadeh, 2002). Khan et al. (2008) investigated that zinc application had positive impact on plant growth which lead to increase plant height, number of fertile tillers $\mathrm{m}^{-2}$, spike length, grains spike ${ }^{-1}$, biological yields and culminating in better grain yield. Maximum number of productive tillers was noted in the plots treated with $10 \mathrm{~kg} \mathrm{Fe}$ $\mathrm{ha}^{-1}$. This might be due to Fe has marked role in cellular events and mitochondrial homeostasis which in turn effect the plant growth and development (Vigani et al., 2013). Application of Fe at different levels hastened the number of tillers, 1000 grains weight and grain yield of the wheat (Abbas et al., 2012). Rawashdeh \& Sala (2014) studied the importance of Fe in the enhancement of quantitative and qualitative specifications of 
the wheat grain which significantly increase the number of fertile tillers and plant height. Boorboori et al. (2012) reported that soil application of $\mathrm{Zn}$ and Fe has positive impact on fertile tillers and more productive tillers were attained through soil application of $\mathrm{Zn}$ and Fe.

Plant height is a function of combined effect of both genetic and environmental factors. Significant differences were observed in plant height as a result of different $\mathrm{Zn}$ and Fe levels. The treatments against control were found significant, while interaction of $\mathrm{Zn}$ and $\mathrm{Fe}$ was found non-significant (Table 2). Mean values of data exposed that fertilization of 15 $\mathrm{kg} \mathrm{Zn} \mathrm{ha-1}$ resulted in taller plants (94), which was statistically comparable with the plant height (93) obtained at $20 \mathrm{~kg} \mathrm{Zn}$ $\mathrm{ha}^{-1}$. Short statured plants (90) were noted at $5 \mathrm{~kg} \mathrm{Zn} \mathrm{ha-}$ ${ }^{1}$ treated plots. Among different Fe levels, taller plants (94) were produced by plots treated with Fe at the rate of $10 \mathrm{~kg}$ ha $^{-1}$, which was statistically comparable with the plants (93) established by $5 \mathrm{~kg} \mathrm{Fe} \mathrm{ha}^{-1}$ treated plots. Dwarf plants (90) were developed with $20 \mathrm{~kg} \mathrm{Fe} \mathrm{ha}^{-1}$. Furthermore, treated plots improved the plant height (92) in a momentous way over control (87). It might be due to the maximum availability and absorption of $\mathrm{Zn}$ from soil solution which increase photosynthesis rate, respiration rate, auxin metabolism, cytochrome synthesis and faster cell division and root-shoot development consequently heighten wheat plants (Mahdi et al., 2012). $\mathrm{Zn}$ is an essential micro element in growth and development of plant (Badshah \& Ayub, 2013). Taller plants were noticed in the plots treated with $10 \mathrm{~kg} \mathrm{Fe} \mathrm{ha}^{-1}$. Fe has an imperative role in photosynthetic reactions and triggers several enzymes that contributes in RNA synthesis and improve plant growth (Malakouti \& Tehrani, 2005). Bameri et al. (2012) reported in a field experiment that $\mathrm{Zn}, \mathrm{Fe}$ and $\mathrm{Mn}$ had positive effect plant height, 1000-grains weights, grains yield, biological yields and harvests index.

Significant differences were observed in days to maturity as consequences of different levels of $\mathrm{Zn}$ and Fe. The treatments against control were found significant, while interactive effect of $\mathrm{Zn}$ and Fe was found insignificant (Table 2). Means of data presented that maximum days to physiological maturity (160) were recorded at $15 \mathrm{~kg} \mathrm{Zn} \mathrm{ha}^{-1}$, which were followed by days to physiological maturity (159) noted with both 10 and $20 \mathrm{~kg} \mathrm{Zn} \mathrm{ha-1}^{-1}$ treated plots. Early physiological maturity (158) was observed at $5 \mathrm{~kg} \mathrm{Zn} \mathrm{ha-1}$. Among different Fe levels, more days to physiological maturity (160) were resulted in the plots with $10 \mathrm{~kg} \mathrm{Fe} \mathrm{ha}^{-1}$, which was followed by days to physiological maturity (159), obtained with the 15 and $20 \mathrm{~kg} \mathrm{Fe} \mathrm{ha}^{-1}$ treated plots. Fewer days to maturity (158) were recorded with fertilization of $5 \mathrm{~kg} \mathrm{Fe} \mathrm{ha}^{-1}$. The control plots against fertilized plots took least days to physiological maturity (157). Delay in maturity might be due to $\mathrm{Zn}$ cause rise in the chlorophyll contents, similarly, might enhance the level of indole acetic acids which is consider to be one of the plants indispensable hormones, necessary both for growth and development (McCauley et al., 2009). Asif et al. (2013) demonstrated that $\mathrm{Zn}$ application increase nitrogen uptake, which improve vegetative growth and delayed days to maturity. Determined days to maturity were observed in the plots fertilized with $10 \mathrm{~kg} \mathrm{Fe} \mathrm{ha}^{-1}$. Fe plays critical role in plant growth and development, inclusive of chlorophyll formation, thylakoid synthesis, nitrogen fixation and enzymatic activities of photosynthesis along with respiration (Masoud et al., 2012).

Better nutrition enhanced the source capacity to better fill the sink. Significant differences were observed for grains spike ${ }^{-1}$ as a result of $\mathrm{Zn}$ and Fe levels. The treatments against control were found significant, while the interaction of $\mathrm{Zn}$ with Fe was discovered insignificant (Table 3). Mean values of the data resulted that $\mathrm{Zn}$ at the rate of $15 \mathrm{~kg} \mathrm{ha}^{-1}$ produced more grain spike-1 $(52)$, which was statistically at for with grain spike ${ }^{-1}$

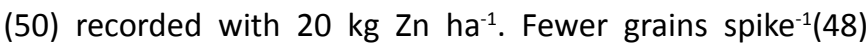
were observed in the plots treated with $10 \mathrm{~kg} \mathrm{Zn} \mathrm{ha}^{-1}$. Among different Fe levels, Fe at the rate of $10 \mathrm{~kg} \mathrm{ha}^{-1}$ produced more grains spike $e^{-1}(54)$, which was followed by grains spike $e^{-1}(50)$

Table 2. Days to anthesis, productive tillers $\left(\mathrm{m}^{2}\right)$, days to maturity and plant height $(\mathrm{cm})$ of wheat as affected by zinc and iron. The University of Agriculture Peshawar, 2015/2016.

\begin{tabular}{|c|c|c|c|c|}
\hline Zinc $\left(\mathrm{kg} \mathrm{ha}^{-1}\right)$ & Days to anthesis & Productive tillers $\left(\mathrm{m}^{2}\right)$ & Days to maturity & Plant height $(\mathrm{cm})$ \\
\hline 5 & $124 \mathrm{a}$ & $281 \mathrm{c}$ & $158 \mathrm{c}$ & $90 \mathrm{~b}$ \\
\hline 10 & $122 \mathrm{~b}$ & $293 \mathrm{~b}$ & $159 \mathrm{~b}$ & $91 \mathrm{~b}$ \\
\hline 15 & $121 \mathrm{c}$ & 299 a & $160 \mathrm{a}$ & $94 a$ \\
\hline 20 & $120 d$ & $291 \mathrm{~b}$ & $159 b$ & 93 a \\
\hline LSD for zinc (Zn) & 0.9 & 5.6 & 0.8 & 1.7 \\
\hline \multicolumn{5}{|l|}{ Iron $\left(\mathrm{kg} \mathrm{ha}^{-1}\right)$} \\
\hline 5 & $124 \mathrm{a}$ & $296 a$ & $158 \mathrm{c}$ & 93 a \\
\hline 10 & $122 \mathrm{~b}$ & 298 a & $160 \mathrm{a}$ & 94 a \\
\hline 15 & $121 \mathrm{c}$ & $288 \mathrm{~b}$ & $159 \mathrm{~b}$ & $91 \mathrm{~b}$ \\
\hline 20 & $120 \mathrm{~d}$ & $282 c$ & $159 \mathrm{~b}$ & $90 \mathrm{~b}$ \\
\hline LSD for iron (Fe) & 0.9 & 5.6 & 0.8 & 1.7 \\
\hline Planned mean comparison & ** & ** & * & ** \\
\hline Control & 126 & 244 & 157 & 86.9 \\
\hline Rest & 122 & 291 & 159 & 92.0 \\
\hline \multicolumn{5}{|l|}{ Interaction } \\
\hline LSD for $\mathrm{Zn} \times \mathrm{Fe}$ & ** & ns & ns & ns \\
\hline
\end{tabular}

** and ${ }^{*}=$ significant at $1 \%$ and $5 \%$ level of probability, $\mathrm{ns}=$ non-significant

Mean values of the different categories in each column with different letters discloses significant differences ( $p \leq 0.05)$ using LSD test. 
obtained with both 5 and $15 \mathrm{~kg} \mathrm{Fe} \mathrm{ha}^{-1}$. Fewer grain spike ${ }^{-1}$ (45) was produced with the $20 \mathrm{~kg} \mathrm{Fe} \mathrm{ha}^{-1}$. The control against the treated plots resulted in fewer grain spike ${ }^{-1}(36)$. It might be due to the enhancement of enzymatic processes. Microelements efficiently enhanced the photosynthesis and translocate assimilates to seed. In a long-term experiment, Hao et al. (2003) concluded that fertilization of $\mathrm{Zn}$ improved the nutritional value, grains spike ${ }^{-1}$ and thousand grain weight per unit area. The grains spike ${ }^{-1}$ increases in plots treated with $10 \mathrm{~kg} \mathrm{Fe} \mathrm{ha-1}$. This might be due to better starch utilization and translocation of assimilates to developing grains, which increase the grain size and grains spike ${ }^{-1}$. Nadim et al. (2013) demonstrated that grains spike ${ }^{-1}$ in wheat are improved with the soil application of Fe. Fathi \& Enayat Gholizadeh (2010) demonstrated that increased level of $\mathrm{Zn}$ and Fe as soil fertilizer increases grain yield, 1000 grain weight and grains spike ${ }^{-1}$ in barley plant.

Analysis exhibited that different $\mathrm{Zn}$ and Fe levels significantly affected thousand grains weight of wheat. The treatments against control were found significant, while the interaction effect of $\mathrm{Zn}$ with Fe was illustrated insignificant (Table 3). Mean values of the data indicated that $\mathrm{Zn}$ at the rate of $15 \mathrm{~kg} \mathrm{ha}^{-1}$ attained more 1000 grains weight (45.5), which was followed by thousand grains weight (44.4) produced with $20 \mathrm{~kg} \mathrm{Zn} \mathrm{ha-1}$. Lighter thousand grains (43.2) were recorded with $5 \mathrm{~kg} \mathrm{Zn} \mathrm{ha}^{-1}$. Among different Fe levels, Fe at the rate of $10 \mathrm{~kg} \mathrm{ha}^{-1}$ documented heavier grains (45.4), which were followed by thousand grains weight (44.6) obtained with $5 \mathrm{~kg} F e \mathrm{ha}^{-1}$. Minimum thousand grains (42.9) weight was produced with $20 \mathrm{~kg} \mathrm{Fe} \mathrm{ha-1.} \mathrm{The} \mathrm{control} \mathrm{plots} \mathrm{in} \mathrm{comparison}$ with the fertilized plots produced less thousand grains weight (39.2). This perhaps due to the fact that $\mathrm{Zn}$ plays key role in biosynthesis of IAA, synchronizing the auxin concentration in plant and other biochemical and physiological processes and initiation of primordia for reproductive parts and thus ascribed the beneficial effect of to better translocation of desired metabolites to the yield contributing parts of plant. The increase in yield attributing characters like spike length, grains spike ${ }^{-1}$, number of effective tillers and 1000-grain weight with $\mathrm{Zn}$ application has been reported by Bameri et al. (2012). Soil application of $\mathrm{Zn}$ hastens wheat $\mathrm{Zn}$ dietary standard and improve spike number, grains spike ${ }^{-1}$ and 1000-grain weight (Hao et al., 2003). Heavier grains were documented with fertilization of $10 \mathrm{~kg} \mathrm{Fe} \mathrm{ha}^{-1}$. This perhaps due to the key role of $\mathrm{Fe}$ in plant respiration, photosynthetic processes and chlorophyll formation, addition of Fe improves grain yield components. Application of $\mathrm{Zn}, \mathrm{Mn}$ and Fe have key importance in crop growth, involving in photosynthesis, respiration and other biochemical and physiological processes and thus attributed to higher yields (Zeidan et al., 2010). Application of $Z n$ with Fe improves 1000 grain weight in rice in comparison to sole application of $\mathrm{Zn}$ and Fe (Zayed et al., 2011).

Grain yield was suggestively exaggerated by different zinc $(\mathrm{Zn})$ and iron (Fe) levels. The comparison of control plots vs treated plots was also found significant, while the interaction had non-significant response for $\mathrm{Zn}$ and Fe (Table 3). Mean values of the data revealed that $\mathrm{Zn}$ at the rate of $15 \mathrm{~kg} \mathrm{ha}^{-1}$ produced greater grain yield (3775 kg ha-1), which was statistically comparable with grain yield (3751 $\mathrm{kg} \mathrm{ha}^{-1}$ ) produced with the 20 . $\mathrm{kg} \mathrm{Zn} \mathrm{ha}^{-1}$. The grain yield (3496 kg ha-1) was lower with the $5 \mathrm{~kg} \mathrm{Zn} \mathrm{ha}^{-1}$. Among different Fe levels, Fe .at the rate of $10 \mathrm{~kg} \mathrm{ha}^{-1}$ produced more grain yield $(3802 \mathrm{~kg}$ $\mathrm{ha}^{-1}$ ), which was statistically at par with the grain yield (3747 $\mathrm{kg} \mathrm{ha}^{-1}$ ) obtained with the $5 \mathrm{~kg} \mathrm{Fe} \mathrm{ha}^{-1}$. Lower grain yield (3449 $\mathrm{kg} \mathrm{ha}^{-1}$ ) was produced with the $20 \mathrm{~kg} \mathrm{Fe} \mathrm{ha}^{-1}$. The control plots in comparison with the rest plots produced lower grain yield (2919 $\mathrm{kg} \mathrm{ha}^{-1}$ ). This improvement in the grain yield might be due to the fact that $\mathrm{Zn}$ has catalytic role in photosynthesis, respiration, biochemical and physiological activities and thus result in higher grain yield (Dahiya et al., 2008). Zn contributes in conversion of nitrates to ammonia and here after, improve

Table 3. Grain spike ${ }^{-1}$, thousand grain weight $(\mathrm{g})$ and grain yield $\left(\mathrm{kg} \mathrm{ha}^{-1}\right)$ and harvest index (\%) of wheat as affected by zinc and iron. The University of Agriculture Peshawar, 2015/2016.

\begin{tabular}{|c|c|c|c|c|}
\hline Zinc (kg ha-1) & Thousand grain weight (g) & Grain spike $^{-1}$ & Grain yield (kg ha-1) & Harvest index (\%) \\
\hline 5 & $43.2 \mathrm{c}$ & $49 \mathrm{~b}$ & $3496 \mathrm{c}$ & $44.47 \mathrm{~b}$ \\
\hline 10 & $43.7 \mathrm{c}$ & $48 a b$ & $3592 b$ & $44.71 \mathrm{a}$ \\
\hline 15 & $45.5 a$ & $52 a$ & $3775 a$ & $45.88 \mathrm{a}$ \\
\hline 20 & $44.4 b$ & $50 a$ & $3751 a$ & $45.90 \mathrm{a}$ \\
\hline LSD for zinc (Zn) & 0.7 & 2.9 & 55 & 1.2 \\
\hline \multicolumn{5}{|l|}{ Iron (kg ha-1) } \\
\hline 5 & $44.6 \mathrm{~b}$ & $50 \mathrm{~b}$ & $3747 a$ & $45.50 \mathrm{a}$ \\
\hline 10 & $45.4 \mathrm{a}$ & $54 a$ & $3802 \mathrm{a}$ & $46.08 \mathrm{a}$ \\
\hline 15 & $43.9 \mathrm{~b}$ & $50 \mathrm{~b}$ & $3616 b$ & $44.85 \mathrm{ab}$ \\
\hline 20 & $42.9 c$ & $45 c$ & $3449 \mathrm{c}$ & $44.53 a b$ \\
\hline LSD for iron(Fe) & 0.7 & 2.9 & 55 & 1.2 \\
\hline Planned mean comparison & $* *$ & $* *$ & $* *$ & $* *$ \\
\hline Control & 39.2 & 36 & 2919.1 & 42.6 \\
\hline Rest & 44.2 & 49 & 3653.5 & 45.2 \\
\hline \multicolumn{5}{|l|}{ Interaction } \\
\hline LSD for $\mathrm{Zn} \times \mathrm{Fe}$ & ns & ns & ns & ns \\
\hline
\end{tabular}

** = significant at $1 \%$ level of probability and $\mathrm{ns}=$ non-significant

Mean values of the different categories in each column with different letters discloses significant differences ( $p \leq 0.05)$ using LSD test. 
grain yield of wheat by $4-9 \%$ (Thakur et al., 2001). The grain yield increases in plots treated with $10 \mathrm{~kg} \mathrm{Fe} \mathrm{ha}^{-1}$. This might be due to the fact that Fe has a vital role in the plant respiration and photosynthesis thereby translocate more assimilates toward source which result in higher grain yield. Abbas et al. (2009) reported increased grain yield of wheat by the application of Fe whereas the higher rate of Fe had insignificant influence on crop yield.

Harvest index is an indicator of dry matter partitioning towards the reproductive organs. Harvest index of wheat was significantly affected by different zinc ( $\mathrm{Zn}$ ) and iron (Fe) levels. The comparison of control vs rest was also found significant, while the interactive effect of $\mathrm{Zn}$ and Fe was found nonsignificant (Table 13). Mean values of the data shown that $\mathrm{Zn}$ at the rate of $20 \mathrm{~kg} \mathrm{ha}^{-1}$ had higher harvest index (45.90), which was statistically similar with the harvest index (45.88) attained with $15 \mathrm{~kg} \mathrm{Zn} \mathrm{ha-1}$. The harvest index (44.47) was lower with the $5 \mathrm{~kg} \mathrm{Zn} \mathrm{ha}{ }^{-1}$. Among different Fe levels, Fe at the rate of 10 $\mathrm{kg} \mathrm{ha}^{-1} \mathrm{had}$ more harvest index (46.08), which was statistically at par with the harvest index (45.50) attained with the $5 \mathrm{~kg} \mathrm{Fe}$ $\mathrm{ha}^{-1}$. Lower Harvest index (44.53) was obtained with the $5 \mathrm{~kg}$ Fe ha ${ }^{-1}$. The control plots in comparison with the fertilized plots had lower Harvest index (42.6). This might be due to sufficient $\mathrm{Zn}$ nutrition which improve cell division, photosynthesis, respiration, nitrogen metabolism, protein synthesis and physiological activates which is therefore, reflected in better straw, grain yield as well as harvests index (Sharma et al., 2013) Dehghanian \& Madandoost (2008) exhibited that linear $\mathrm{Zn}$ inclination enhance harvest index. Higher harvest index noted with application of $10 \mathrm{~kg} \mathrm{Fe} \mathrm{ha}^{-1}$. This perhaps due to the basic role of $\mathrm{Fe}$ in plant respiration, photosynthetic processes and chlorophyll formation, Fe addition cause improvement in grain yield components. Application of micro-elements prominently improve grains spike ${ }^{-1}, 1000$ grains weight, tillers meters $^{-2}$, grain yield, biological yields and harvest index of the wheat (Zain et al., 2015).

\section{Conclusions}

Fe and $\mathrm{Zn}$ uptake are controlled by the two major factors, availability of these elements in the soil and the ability of plants to acquire them. Exogenous application of $\mathrm{Zn}$ and Fe is simple and easy method to correct their deficiency in the soil and plants. The available results exhibited that exogenous application of $\mathrm{Zn}$ and $\mathrm{Fe}$ at the rate of 15 and $10 \mathrm{~kg} \mathrm{ha}^{-1}$ enhanced phenology, yield and yield components of wheat and therefore recommended for higher productivity of wheat under agro-climatic condition of Peshawar.

\section{Acknowledgments}

This study was conducted in the Agronomy Research Farm of The University of Agriculture Peshawar-Pakistan. This article is part of the master's thesis of the first author.

\section{Literature Cited}

Abbas, G.; Hussain, F.; Anwar, Z.; Khattak, J. Z. K.; Ishaque, M.; Asmat, U. Effects of iron on the wheat crop (Triticum aestivum L.) by uptake of nitrogen, phosphorus and potassium. Asian Journal of Agricultural Sciences, v.4, n.3, p.229-235, 2012. https:// maxwellsci.com/print/ajas/v4-229-235.pdf. 06 Sep. 2019.

Abbas, G.; Khan, M.Q.; Khan, M.J.; Hussain, F.; Hussain, I. Effect of iron on the growth and yield contributing parameters of wheat (Triticum aestivum L.). The Journal of Animal and Plant Sciences, v. 19, n.3, p.135-139, 2009. http://thejaps.org.pk/ docs/19-no-3-2009/09-935.pdf. 25 Aug. 2019.

Asif, M.; Saleem, M.F.; Anjum, S.A.; Wahid, M.A.; Bilal, M.F. Effect of nitrogen and zinc sulphate on growth and yield of maize (Zea mays L.). Journal of Agricultural Research, v.51, n.4, p.455-464, 2013. https://pdfs.semanticscholar.org/4542/5a78a8692183cbc 308057a3cceef4f6df3bf.pdf. 02 Aug. 2019.

Badshah, N.L.; Ayub, A. Effect of different concentrations of nitrogen and zinc on the growth of pecan nut seedlings. Journal of Agricultural and Biological Science, v.8, n.4, p.337-343, 2013. http://www.arpnjournals.com/jabs/research_papers/rp_2013/ jabs_0413_559.pdf. 01 Sep. 2019.

Bameri, M.; Abdolsahi, R.; Mohammadi-Nejad, G.; Yousefi, K.; Tabatabaie, S. M. Effect of different microelement treatment on wheat (Triticum aestivum L.) growth and yield. International Research Journal of Applied and Basic Sciences, v.3, n.1, p.219-223, 2012. https://pdfs.semanticscholar.org/5bf7/ d30a012312cbf8e674a2dea490230faa0e3c.pdf. 01 Sep. 2019.

Black, C.A. (Ed.). Methods of Soil Analysis: Part 1, physical and mineralogical properties, including statistics of measurement and sampling. Madison: American Society of Agronomy; Soil Science Society of Agronomy, 1965a. (Agronomy Monograph, 9.1). https://doi.org/10.2134/agronmonogr9.1.frontmatter.

Black, C.A. (Ed.). Methods of Soil Analysis: Part 2, chemical and microbiological properties. Madison: American Society of Agronomy; Soil Science Society of Agronomy, 1965b. (Agronomy Monograph, 9.2). https://doi.org/10.2134/ agronmonogr9.2.frontmatter.

Boorboori, M.R.; Asli, E.; Tehrani, M.M. Effect of micronutrient application by different methods on yield, morphological traits and grain protein percentage of barley (Hordeum vulgare L.) in greenhouse conditions. Revista Científica UDO Agrícola, v.12, n.1, p.127-134, 2012. http://udoagricola.orgfree.com/V12N1UDOAg/ V12N1Boorboori127.pdf. 25 Aug. 2019.

Bremner, J.M.; Mulvaney, C.S. Nitrogen - Total. In: Black, C.A. (Ed.). Methods of soil analysis: Part 2, chemical and microbiological properties. 2.ed. Madison: American Society of Agronomy, Soil Science Society of America, 1982. Chap. 31, p.595-624. (Agronomy Monograph, 9.2). https://doi.org/10.2134/agronmonogr9.2.2ed. c31.

Cakmak, I. Enrichment of cereal grains with zinc: agronomic or genetic biofortification. Plant and Soil, v.302, n.1-2, p.1-17, 2008. https://doi.org/10.1007/s11104-007-9466-3.

Cakmak, I. Plant nutrition research priorities to meet human needs for food in sustainable ways. Plant and Soil, v.247, n.1, p.3-24, 2002. https://doi.org/10.1007/978-94-017-2789-1_1. 
Dahiya, R.R.; Dahiya, S.S.; Singh, D. Evaluation of NPZn (10: 50: 1.5 $\mathrm{Zn)}$ complex fertilizer in rice wheat cropping system. Indian Journal of Agricultural Research, v. 42, n.4, p.288-292, 2008. https://arccjournals.com/journal/indian-journal-of-agriculturalresearch/ARCC2317. 27 Aug. 2019.

Dehghanian, M.; M. Madondoost. Effect of Zinc chelate on drought tolerance of wheat (Triticum aestivum L.). JWSS, v.12, n.45, p.393401, 2008. http://jstnar.iut.ac.ir/article-1-928-en.html. 28 Jul. 2019.

Fathi, G. H.; Gholizadeh, M. E. Effect of fertilizers with trace elements of Zn, $\mathrm{Fe}$ and $\mathrm{Cu}$ on growth and grain yield of barley in Khoozestan climate. Scientific Journal of Farm Plant Physiology, v.1, p.53-67, 2010.

Hafeez, B.; Y.M. Khanif.; M. Saleem. Role of Zinc in Plant Nutrition- A Review. American Journal of Experimental Agriculture, v.3, n.2, p. 374-391, 2013. https://doi.org/10.9734/AJEA/2013/2746.

Hao, M. D.; Wei, X. R.; Dang, T. H. Effect of long-term applying zinc fertilizer on wheat yield and content of zinc in dryland. Plant Nutrition and Fertilizer Science, n.3, p.377-380, 2003.

Havlin, J. L.; Tisdale, S. L.; Nelson, W. L.; Beaton, J. D. Soil fertility and fertilizers. 8.ed. New Jersey: Prentice Hall, 2014. 528 p.

Jalilvand, S.; Roozbahani, A.; Hasanpour, J. Effect of foliar application of Iron on morphophysiological traits of wheat under drought stress. Bulletin of Environment, Pharmacology and Life Sciences, v.3, special issue-V, p.167-177, 2014. http://www.bepls.com/ spl_v_2014/30.pdf. 02 Aug. 2019.

Keram, K.S.; Sharma, B.L.; Kewat, M.L.; Sharma, G.D. Effect of zinc fertilization on growth, yield and quality of wheat grown under agro-climatic condition of Kymore Plateau of Madhya Pradesh, India. The BioScan, v. 9, n. 4, p.1479-1483, 2014. https://www. cabdirect.org/cabdirect/abstract/20153130046. 29 Aug. 2019.

Khan, M.; Fuller, M.; Baloch, F. Effect of soil applied zinc sulphate on wheat (Triticum aestivum L.) grown on a calcareous soil in Pakistan. Cereal Research Communications, v.36, n.4, p.571-582, 2008. https://doi.org/10.1556/CRC.36.2008.4.6.

Mahdi, S.S.; Hasan, B.; Singh, L. Influence of seed rate, nitrogen and zinc on fodder maize (Zea mays) in temperate conditions of western Himalayas. Indian Journal of Agronomy, v. 57, n.1, p.8588, 2012. https://www.indianjournals.com/ijor.aspx?target=ijor:i ja\&volume=57\&issue=1\&article=015. 02 Aug. 2019.

Malakouti, M.; Tehrani, M. Micronutrient role in increasing yield and improving the quality of agricultural products. 1.ed. Tehran: Tarbiyat Modarress University, 2005. Chap. 46, p.1200-1250.

Masoud, M.S.; Ali, A.E.; Shaker, M.A.; Elasala, G.S. Synthesis, computational, spectroscopic, thermal and antimicrobial activity studies on some metal-urate complexes. Spectrochimica Acta Part A: Molecular and Biomolecular Spectroscopy, v. 90, p.93108, 2012. https://doi.org/10.1016/j.saa.2012.01.028.

McCauley, A.; Jones, C.; Jacobsen, J. Plant nutrient functions and deficiency and toxicity symptoms. Bozeman: Montana State University, 2009. 16p. (Nutrient Management. Module, 9). http://landresources. montana.edu/nm/documents/NM9.pdf. 02 Aug. 2019.

Mclean, E.O. Soil pH and lime requirement. In: Black, C.A. (Ed.). Methods of soil analysis: Part 2, chemical and microbiological properties. 2.ed. Madison: American Society of Agronomy, Soil Science Society of America, 1982. Chap 12, p.199-224. (Agronomy Monograph, 9.2). https://doi.org/10.2134/agronmonogr9.2.2ed. c12.
Mengel, K.; Kirkby, E.A.; Kosegarten, H.; Appel, T. Further elements of importance. In: Mengel, K.; Kirkby, E.A.; Kosegarten, H.; Appel, T. (Eds.). 5.ed. Principles of plant nutrition. Dordrecht: Springer Science, 2001. p. 639-655. https://doi. org/10.1007/978-94-010-1009-2_19.

Mosanna, R.; Behrozyar, E.K. Morpho-physiological response of maize (Zea mays L.) to zinc nano-chelate foliar and soil application at different growth stages. Journal on $\mathrm{New}$ Biological Reports, v.4, n.1, p.46-50, 2015. https://www. researchtrend.net/jnbr/jnbr/VOL\%203(3)\%202014/8\%20 Mosanna\%20and\%20Ebrahim\%20\%20JNBR_4(1)\%20_2015. pdf. 05 Sep. 2019.

Mousavi, S.R.; Galavi, M.; Rezaei, M. Zinc (Zn) importance for crop production - a review. International Journal of Agronomy and Plant Production, v. 4, n.1, p.64-68, 2013. https://www. researchgate.net/publication/285026142. 02 Aug. 2019.

Nadim, M.A.; Awan, I.U.; Baloch, M.S.; Khan, N.; Naveed, K.; Khan, M.A. Micronutrient use efficiency in wheat as affected by different application methods. Pakistan Journal of Botony, v. 45, n.3, p.887-892, 2013. https://www.pakbs.org/pjbot/ PDFs/45(3)/22.pdf. 06 Sep. 2019.

Nelson, D.W.; Sommers, L.E. Total carbon, organic carbon, and organic matter. In: Black, C.A. (Ed.). Methods of soil analysis: Part 3, chemical methods. Madison: American Society of Agronomy; Soil Science Society of Agronomy, 1996. Chap. 34, p.961-1010. (SSSA Book. Series, 5.3). https://doi.org/10.2136/ sssabookser5.3.c34.

Rawashdeh, M.; Sala, F. Influence of iron foliar fertilization on some growth and physiological parameters of wheat at two growth stages. Romania Scientific Papers. Series A. Agronomy, v.57, p.306-309, 2014. http://agronomyjournal.usamv.ro/ pdf/2014/art54.pdf. 25 Aug. 2019.

Sharma, A.; Patni, B.; Shankhdhar, D.; Shankhdhar, S.C. Zinc an indispensable micronutrient. Physiology and Molecular Biology of Plants, v.19, n.1, p.11-20, 2013. https://doi. org/10.1007/s12298-012-0139-1.

Soltanpour, P.A.; Schwab, A.P. A new soil test for simultaneous extraction of macro- and micro-nutrients in alkaline soils. Communications in Soil Science and Plant Analysis, v. 8, n.3, p.195-207, 1977. https://doi. org/10.1080/00103627709366714.

Tahir, M. A.; Naz, S; Noorka, I. R. Zinc enrichment of wheat plant; a new strategy to improve human nutrition and health. International Journal of Medical and Applied Health, v.1, n.1, p.6-9, 2013.

Thakur, H.S.; Raghuwanshi, R.K.S.; Sharma, R.A.; Sinha, N.K. Long term effects of sulphur and zinc fertilization in soybean (Glycine max)-wheat (Triticum aestivum) cropping system. Crop Research Hisar, v. 21, n.3, p.283-286, 2001.

Vankhadeh, S. Response of sunflower to applied Zn, Fe, P, N. Nes. S. Zz., v.1, p.143-144, 2002.

Vigani, G.; Morandini, P.; Murgia, I. Searching iron sensors in plants by exploring the link among 2'-OG-dependent dioxygenases, the iron deficiency response and metabolic adjustments occurring under iron deficiency. Frontiers in Plant Science, v.4, article 169, 2013. https://doi.org/10.3389/fpls.2013.00169. 
White, P. J.; Broadley, M. R. Biofortification of crops with seven mineral elements often lacking in human diets-iron, zinc, copper, calcium, magnesium, selenium and iodine. New Phytologist, v.182, n.1, p.49-84, 2009. https://doi.org/10.1111/j.14698137.2008.02738.x.

Zain, M.; Khan, I.; Qadri, R.W.K.; Ashraf, U.; Hussain, S.; Minhas, S.; Siddiquei, A.; Jahangir, M.M.; Bashir, M. Foliar application of micronutrients enhances wheat growth, yield and related attributes. American Journal of Plant Sciences, v. 6, n.7, p.864, 2015. https://doi.org/10.4236/ajps.2015.67094.
Zayed, B. A.; Salem, A. K. M.; Sharkawy, H. M. Effect of different micronutrient treatments on rice (Oryza sativa L.) growth and yield under saline soil conditions. World Journal of Agricultural Science, v.7, n.2, p.179-184, 2011. https://www.idosi.org/wjas/ wjas7(2)/12.pdf. 02 Aug. 2019

Zeidan, M. S.; Mohamed, M. F.; Hamouda, H. A. Effect of foliar fertilization of $\mathrm{Fe}, \mathrm{Mn}$ and $\mathrm{Zn}$ on wheat yield and quality in low sandy soils fertility. World Journal of Agricultural Science, v.6, n.6, p.696-699, 2010. https://www.idosi.org/wjas/wjas6(6)/11. pdf. 02 Aug. 2019. 